\title{
Façades of gothic Mediterranean cathedrals and fortifications. Constructive racionality facing earthquake
}

\author{
Fachadas de catedrales y fortificaciones del Gótico Mediterráneo. Racionalidad constructiva \\ frente al terremoto
}

Víctor Manuel Santiago Pedraza (Main and Corresponding Author)

Escuela Técnica Superior de Arquitectura de Madrid, DCTA.

Ronda del Arroyo no 11 2 C 45006, Toledo (Spain)

vm.santiago@alumnos.upm.es

Manuscript Code: 585

Date of Acceptance/Reception: 03.08.2017/31.01.2015

DOI: 10.7764/RDLC.16.2.202

\begin{abstract}
This study continues the research taken by the teacher Cassinello, Doctoral Thesis "Seismic rationality in Gothic architecture: structural and building types" (Cassinello, 2005), where she checks the special constructive facing earthquakes configuration of Spanish cathedrals, subdividing them in structures Types A or B. Types B have large spandrels on the arches, flat terraces, hidden buttresses and horizontal facades with very vertical windows. The target is to show how these facades of cathedrals and fortifications in the Spanish Mediterranean have special facing earthquake's configuration being the essential key for the building stability. In order to do it we select and analyse various samples. The Method of the equivalents and horizontals forces and the Analysis of confined masonry defines the design's principles founds in these facades. Analytical methods relating horizontal areas of façades and areas of buildings, or vertical and horizontal spaces between windows and graphic methods with parabolic arcs or compressed prisms saving the vertical windows provide us comparative results. His analysis allows us how to classify the ability of each façade facing earthquake forces and drawing conclusions that demonstrate this special design.
\end{abstract}

Key words: Horizontal equivalent forces, confined masonry, flat terraces, compressed prims, parabolic arcs.

Resumen

El estudio avanza en la investigación emprendida por la profesora Cassinello, Tesis Doctoral "Racionalidad sísmica en la arquitectura ojival: tipos estructurales y constructivos" (Cassinello, 2005), donde comprueba la configuración constructiva antisismo de las catedrales españolas detectando dos Tipos estructurales A y B. Las Tipo B poseen enjutas sobre arcos, cubiertas aterrazadas, contrarrestos ocultos y fachadas horizontales con huecos muy verticales. El objetivo es analizar cómo fachadas de catedrales y fortificaciones del Levante Mediterráneo español adquieren especial configuración antisismo siendo clave en la estabilidad de conjunto, seleccionando para ello diversas muestras. El método de fuerzas horizontales equivalentes y el análisis de mampostería confinada describen principios estructurales de diseño existentes en estas Fachadas. Métodos analíticos que relacionan áreas horizontales de fachadas y edificio, espacios verticales y horizontales entre huecos y métodos gráficos con arcos parabólicos o prismas comprimidos salvando los huecos nos aportan resultados comparativos. Su análisis permite clasificar la capacidad de cada Fachada de enfrentar fuerzas provenientes de sismos obteniendo conclusiones que evidencian este especial diseño.

Along the XIII century the medieval masters transfer to Castilla the French Gothic style where they build great cathedrals and fortifications. During the fourteenth century this style was implanted on the Spanish Mediterranean with very different aesthetic and personality, distant of the Gothic aesthetic. The new style maintains formal architectural elements of French Gothic they used here in different way to create a new architecture whose façades transmit great horizontality in cathedrals and built fortresses.

This horizontality is result of several substantial changes making cathedrals, churches and fortifications to resemble between them, something unthinkable in the original Gothic: the cathedrals employ flat terraces, elevating side naves to the height of principal nave and suppressing the cruise nave while fortifications are always cubic or prismatic volumes. Their façades get dominate the wall over windows, removing decorative elements - pinnacles and cornicesand including the buttresses inside them.

These transformations have one main reason: to give the building the greatest possible stability in the more economy way, giving the facades a structural function they lacked, being the main collaborative element in the overall stability. 
Earthquakes are present from the beginning of the construction period of cathedrals and fortresses up to his completion: the medieval masters develop constructive types that make them resistant, even when they have not been closed the vaults or finished the flat decks that anchor the walls.

Some documents like fabrica books or quarry books show us how Gothic masters lived the seismic destructive effects during construction period of cathedrals and fortifications.

Thus, the Church of Santa María del Mar faces several earthquakes during his construction and once finished she faces more than ten earthquakes documented in his Fabric Books and Documentary Archive. The refered data in these documents are summarized here:

02/03/1373 "great earthquake in Barcelona, falling the bell tower .."; 02/01/1376 "there was earthquake in Barcelona". Once finished the church: 03/30/1410 "there was a great earthquake in Barcelona and a great mortality...", 02, 03, 14, 19-22 / 03/1427 and 04/22/1427 "There were earthquakes in Barcelona .. with death .. "02/02/1428" earthquake in Barcelona makes to fall the rosette of Santa Maria and killed twenty-five people, ..they fall castles and many houses ... "11/03/1435; 23/12/1511; 21/12/1605 "earthquakes ...", 1628, 1633,1660 are years where earthquakes are also documented.

Besides the National Geographic Institute dates us in Barcelona the following historical earthquakes and their intensities: 24/05/1448 Cardedeu, Intensity VII-VIII. 7/04/1525 Barcelona, Intensity V. 12/1605 Barcelona, Intensity V.

Near Girona dates us: 05/02/1404 Girona, Intensity VII. 13, 15, 19, and 22/03/1427 Arner, Intensity VIII. 2/02/1428. Queralbs, Intensity IX.

Near Valencia dates: 01/02/1258 Onteniente, Intensity VII-VIII. 18/12/1396 Cullera, Intensity IX. 21/11/1517 Xátiva, Intensity V. 26/12/1598 Oliva, Intensity VII.

Mallorca dates: 18/03/1660 Palma, Intensity VI. In 1668 occurs a partial collapse of the facade of Palma's cathedral, and some structural problems in intersection of façades with their vaults was detected.

So the church of Santa María del Mar faces at least two earthquakes while builts their façades, designed and builted expressly to resist, being a first type reference for the rest of the facades of cathedrals and churches subsequently built in seismic areas.

\section{Description of the problem: The façades of a new school}

The Mediterranean Gothic façades diverge completely from the original gothic style: they belong to the orthogonal lattice that composes the stone skeleton of Gothic churches and fortifications.

In Santa María del Mar, Santa María del Pi, the chapel of the monastery of Pedralbes, Castle of La Roca, or doors of Poblet Monastery we can find ashlars in a very horizontal proportion, thicker mortar joints in higher areas of each façade area and very regular ashlars forming the window frames. The fortifications, always with a compact exterior, remove the windows or reduce them to the minimum.

\section{Façades of churches and cathedrals:}

- $\quad$ They have spandrels on the side arches going further the height of the flat decks.

- They anchor between them the spandrels on the transversal arches (main feature in churches type B) forming an orthogonal lattice.

- They make the windows very verticals, who starts on the flat roofs occupying the space of windows and clerestory.

- $\quad$ The lower floor is conformed by a perimeter of massive chapels, with external slopes.

- The upper floors have uniform thickness without internal filling, outer rows of low height and thick joints.

- $\quad$ Eliminate any decorative element: flying buttresses, cornices and pinnacles are unnecessary.

\section{Façades of fortifications:}

- They are not exempt: they belong to a first centreline structural that extends the entire height of the facade. 
- They hide an interior orthogonal structure made by transversal, side and diagonal arches with spandrels, or barrel vaults who anchor the façades between them forming levels or upper terraces.

- $\quad$ They are part of concentric plants (octogonal or circular) or shapes with cubic geometries.

- They are horizontal, inclined from the base, with rows of low-rise and thick joints in hight levels.

- They do not reduce thickness for his obvious defensive reasons, its thickness is occuped by the resistant buttresses.

We see how properties of façades of fortifications have common elements in façades of churches, achieving an optimal design that places material in such a way that guides the pressure curves in a effective way.

\section{Structural safety in gothic façades}

Berenguer de Montagut, Master of Santa Maria del Mar, intuits that internal efforts have to be comfortably contained within the structure, the more free they are inside, the more safer will be this structure.

Façades increase the number of support points by multiplying the number of perimeter chapels. The main nave form very square sections and secondary naves are very rectangular, reaching up to 16 metres between pillars, arches are bigger than we can find in Romanesque naves or the original gothic. However, they reduce the thickness of walls and facades until a limited value considered safe by the gothic masters (eliminating the uncertain behaviour of the internal filling).

But to know the reason for this design optimal means knowing the principles of the limit analysis, hypothesis needed to analyse the buildings masonry built and their way of collapse:

Principles of limit analysis: Masonry architecture is a composite material resulting from the combination of the stone or brick and mortar, in case he is in balance, has infinite compression resistance, cannot be tensioned and its rows of stones or bricks never slide between them.

Process of collapse: There is only a collapse load, bigger or equal, if you have the correct mechanism, to the real collapse load. For a load, if we find a State of internal stress in balance without violating the condition of the material, this burden is lower to the collapse load.

The geometric shape is inseparable from structural function. The voussoirs of the arch or the blocks of a façade are stable and their mechanical behaviour will be correct if its geometry is also correct. The correct use of stonework, proportion, dimensions and finishes used in the Mediterranean Gothic façade ashlars pursues that inside can register infinite ways of arches - or lines of thrust - which carry the loads to the Foundations.

Any load applied on the walls not being its own weight makes to vary the parabolic line of thrust due to the loads. The actual state of the structure and its line of thrusts can be determined by a simple arc but the Mediterranean Gothic façade can hold infinite number of thrusts, because she is a hyperstatic structure, the wall predominates over the holes.

There are two methods of structural, including structures of masonry architecture: the elastic and plastic calculus.

- The elastic calculation hopes to determine exactly the actual state of the structure. It takes into account the properties of material, deformations, support of the arches.

- The plastic calculation does not determine which is the real state of the structure, but envisages a series of variables in addition to the weight such as wind or earthquake, and by applying a safety factor always obtained a design of the structure below the break limit state.

The façade of Santa María del Mar clearly reflects this "geometric security" concept to ensure its geometry in a permanent state of the structure below the break limit state. The paths of efforts are always within the limits of the masonry, aspect studied extensively by Professor Heyman: the masonry wall will withstand any load, transmitting their efforts through pressure lines to the Foundations, whenever it does not violate the condition of equilibrium or stability, i.e. the burden of collapse that transform the structure in a mechanism is never reached.

To apply the safety factor in this church means to increase the horizontal distance between the windows making them inevitably more narrows. 
Resistance to cutting effort of mortar joints depends on the effort of compression, the resistance to cutting of mortar and the angle of friction of the stone or brick and mortar. Thus walls increase the friction between rows, giving greater resistance to the cut effort to mortar joints so they can never slide (Meli, \& Sánchez, 1997). The blocks have more irregular finishes in the centre of walls and much more regulars when they frame holes.

State of the art

\section{Response of gothic Mediterranean façades to earthquake-resistant requirements}

The structure of a building in seismic area always considers the loads generated by the earthquake, moving the building as an inverted pendulum, and causing deformations in their structure depending on the size, loads or weights of each floor, foundation terrain features, geometry of the building, structural and non-structural materials used, etc.

This analysis compares seismic building requirements and the detected answer in our Façades.

Building configuration: Form of the building as a whole, size, nature and location of elements resistant and nonstructural. It transmits loads to the foundations.

Mediterranean Gothic facades belong to the intrinsic shape of the building, transforming inclined loads in vertical loads and refer them to the foundations.

Scale: The seismic loads depend on the size of the building. The inertia forces caused by seismic loads are higher when more size has the building.

The facades never exceed in scale to the French gothic buildings of 12th century. They contain the mass of its walls - as well as the of pillars- maintaining a strict thickness.

Symmetry: A building is symmetrical with respect to its two principal axes if its geometry is identical in either side of the axis. The lack of symmetry produces eccentricity between the centre of mass and the centre of rigidity, and causes torque on his level.

The facades are accurately symmetrical on its two principal axes because the disappearance of the cruise nave, except for the apses of principal naves. The facades of fortifications aspire to symmetry, conditioned by the geometry of the place.

Height: The height of a building affects directly the period of swing, if you increase the height increases the period.

Limits the height of the facade. Gets a unique or fundamental oscillation period.

Horizontal size: Buildings with very large plants do not respond as a unit. The rigidity of the floor is insufficient to redistribute the horizontal load caused by an earthquake.

The surface of plants is contained to respond uniformly and to avoid building areas that oscillate independently. The intermediate floors distribute loads to facades.

Distribution and concentration of masses: The distribution of the masses must be as uniform as possible on the ground as in height. The variation of mass floor to floor will accompany the variation of stiffness.

The facades distribute uniformly their mass in plant and height, progressively increasing the amount of structure to the outside of each plant and towards the base of facades.

Density of plant structure: The higher density of structure on the ground floor serves to the building to withstand the cutting force of ground floor, the accumulated from upper floors and accumulated of gravity loads. "Density of structure in plant" at ground level is the total area of all the vertical structural elements divided by the gross area.

The density of structure on ground floor in facades increases because the closures of perimeter chapels or sloped walls of fortifications. Density of structure is always located in the perimeter of facades being the pillars of reduced dimensions and helping to reduce the "pendulum" effect caused by the earthquake.

Rigidity: Capacity of a structural element or object to be deformed. Ratio between load and deformation that this produces. Joints between components of a structure has a decisive influence on its rigidity. 
They acquire its maximum rigidity on ground floor because the density of structure while in upper floors when she cross the external buttresses increase his inertia moment forming plants in cross.

Flexible floor: When there is a weakness in upper floors or if there is discontinuity in stiffness and strength in vertical structure on a level and the following elements.

There are not flexible floors, on the contrary, there are always intermediate plants that distribute forces and deformations - as in the Cathedral of Barcelona or the gates of Serranos whos facades have inside the buttress.

Corners: Corners are concentrations of efforts if the seismic movement has diagonal direction, even when the rest of the elements are a less requested.

They avoid corners using angles to $45^{\circ}$ with continuity in apses or circular plants. The corners of main facades of temples are very strong.

Torque: Occurs when mass centre and rigidity centre are not coincident. The forces of the quake cause a rotation that distorts the building.

The perfect symmetry and distribution of masses in height make impossible the effects of torque because the mass and rigidity centres are coincident.

Perimetral resistance: Resist torsion in plant supposes to be resisting elements on the perimeter. The lever arm is greater with respect to the centre of rigidity and bigger will be the generated moment.

The facades are the resistance perimeter of the building increasing the lever arm facing torque effects by placing the masse very peripherical in section.

\section{Methods of equivalent horizontal forces and analysis of confined masonry}

It is possible to know stability and behaviour of historical buildings by using principles and current analysis tools, valid for any construction, considering them as qualitative studies (Meli, 1998).

There are tools of analysis and study to understand the structural behaviour of historical buildings. Authors such as Roberto Meli and others made experimental studies of numerical simulation and proposals for reinforcement for old masonry buildings affected by earthquakes. His works show us the application of the principles of structural engineering, its scope and possibilities for future development (Meli, 1975).

Two principles of current structural analysis analysed by qualitative applicability on our facades are:

The confined masonry is a method of construction of walls designed to withstand slabs and roofs, as well as its own weight, in not very high buildings. Puts columns and beams embedded in brick walls, when they are raised. Being part of the structure securing the walls in case of earthquake. The distance between columns is no more than 35 times the thickness of the wall, with a thickness equal to the wall confines them, having a ratio 1 to 25 between the thickness and the maximum height of the Wall. Supports are located on ends, intersections or intermediate places. The thickness is determined by the width of the pieces of masonry employed.

In 1975, Roberto Meli published the results of a series of essays in masonry with different variants. Meli says if there are not significant cracks by bending or diagonal tension, the behaviour of the walls is linear elastic. After of the inclined cracking, they reduce stiffness and resistance. Loads of cracking and maximum reach to distortions with values close to 0.001 and 0.003 , respectively. Distortion is the ratio between the horizontal offset and the height of the wall or floor.

Façades of churches and fortifications of the Mediterranean Gothic have many common points with this analysis:

- $\quad$ Both are designed to withstand earthquakes.

- Orthogonal layout of vertical transverse and resistant walls and horizontal flat terraces) similar in confined masonry. 
- Ratio of 1 to 25 between thickness and high of walls and the maximum distance 35 times the thickness between vertical elements is fulfilled in our facades.

- Cracks inclined in confined masonry similar to those produced in our facades. They are avoided by placing very vertical Windows to carry out the cracks.

- Regular reinforcements of the cracked masonry consist of reinforcement of horizontal joints at high levels of walls, similar to reinforcement consisting of the highest density and thickness of mortar joints in higher areas of façade.

The method of the equivalent horizontal forces is a simplified method of analysis of structures against earthquake included in Technical regulations from different countries, such as Colombia, Ecuador and Spain. Its objective is to: calculate the seismic forces and check the maximum drift of the structure.

This method involves the following steps: determine the spectrum of design, the fundamental period of vibration, of the shearing force in the base and how is distributed in height, making sure that these forces have drift rates not exceeding the permissible value.

It works with a single period corresponding to the fundamental and being a simplified method that applies only in buildings with small number of plants and low height, regular geometrically in plant and elevations, the supports are uniforms and continuous from foundations and having centres of gravity and torque located, approximately, in the same vertical.

Each structural frame is analysed individually. The total seismic force on each level is distributed on the frame in the sense of analysis in accordance with his rigidity considering the effect of rigid diaphragm (flat terraces) that makes all the frame has equal displacement.

The shearing force in the base is the main force that pushes the building on his level of foundations. It is application of the 2nd Newton law $F=m$ a. It is a function of the mass of the building multiplied by a percentage of the force of gravity. This percentage is determined according to the period of vibration of the building that is always the key or mode of vibration in the Spanish Norm. Seismic forces at each height are function of a coefficient of distribution of the shearing force in the base, making a parabolic or almost triangular distribution with value 0 at the base and maximum at the highest level.

The shearing force in the base or Vs is equivalent to all of the horizontal inertial effects produced by design seismic movements, in the study address:

$\mathrm{Vs}=\mathrm{Sg} \mathrm{M}$

where $S$ is a percentage of $g$ acceleration of gravity, which depends on the mode of vibration. When M mass of the building is less, diminished the basal shear.

The values of horizontal seismic force Fx, at any level $x$, in direction of the study, should be determined using the following equation:

$\mathrm{Fx}=\mathrm{C}$ Vs being function of the basal shear. $\mathrm{C}$ is defined:

$C=(m x h x k) / \sum(m i h i k)$

$\mathrm{C}$ is the distribution factor, function of the mass and height on each floor. A similar distribution of masses in each floor (by de flat terraces) makes Fx go increasing in each of the levels, reaching its peak in the highest level of the flat roof or terrace of the main nave. The rest of forces are distributed at the level of each outdoor or interior terrace.

\section{The horizontal forces in the Mediterranean gothic façades}

Earthquakes forces act in perpendicular, parallel or diagonal to the nave of churches and fortifications, although the latter do not have two obvious directions. Its facades act in both cases as a Key element capable of absorbing compression forces coming from the Set of special structural elements designed to withstand these movements such as geometric shape, constructive configuration and type and location of mortar joints, and transmitting them through pressure lines to the Foundations. 
Churches and cathedrals: In perpendicular to the naves the security is maximum because the generalized use of diaphragms arches inherited of dormitories from Poblet Monastery. These churches act as big arches diaphragm giving to buttress the function of extension of those arches. This way, the interior pillars of St. Maria del Mar allow these buttress have a strict measurement (see drawings). These diaphragms, presents in all churches and fortifications of the Mediterranean Levante, are underpinned by pillars of very strict dimensions in churches with three naves. The façade faces these forces acting as anchor and connection of each diaphragm arch. Its geometry determines the proper distribution of the horizontal forces applied at the intersection of exterior walls with floor plants or flat terraces.

Fortifications: They face the horizontal forces when linking between them by diagonal arches, diaphragm arches or barrel vaults. The floor or flat terraces are plants of concentration of mass that anchor the upper and intermediate areas of the facades. They work by transmission and distribution of horizontal forces and deformations they are subjected. They are part of the overall design and they are present in churches and fortifications located in seismic zones.

Methodology

\section{Study of selected samples}

Each selected facade sample is designed in plant, elevation and section. As we know the application points in facade direction of the horizontal forces according to a quasi-triangular distribution that distribute the sharing force, we establish the following analysis methods.

\section{Façades structure density}

Requirement of earthquake resistance, is the ratio between the structural façade elements area and the area of the building on the ground. The structure's facade is the sum of the area of exterior walls, sloped walls, included the internal closures of chapels divided by the area of the building enclosed by the facade on this floor. Comparative data are obtained at each height.

\section{Ratio dimensions vertical / horizontal between gaps}

Relationship between horizontal dimensions existing from window to window and the vertical dimensions from window to the crowning in facades measures both in length and in resistant facade area. Greater distance in vertical dimension will result a higher value and greater resistance of facade. The relationship between areas is the thickness of the façade.

\section{Inscription of parabolic arches}

The inscription on the facades of parabolic arches avoiding the windows reflects the ability of to register in his interior the lines of maximum thrust in case of earthquake. This arches start its vertex on the windows and finish at the level of each terrace - internal or external- acting as point of application and transmission of horizontal forces in façades.

In each arch joins the base point and the upper vertex getting a slanted line that makes an angle with horizontal. If this angle is lower then more resistant is the facade. The arches are placed on each facade: the 3rd facade corresponding to the main nave, the facade 2 nd to the side naves and façade 1 st is the level of the chapels that reach foundations. We get two different arcs according to pass over or under the adjacent window. They correspond to the possible maximum thrust lines produced by earthquakes. Framed windows with very well defined blocks and very thin joints should resist thrusts very close to them.

\section{Inscription of compressed prisms: angle with the horizontal and moments of inertia}

The prisms are more or less inclined according to the intensity of the horizontal forces they face, resisting buckling according to its moment of inertia, reinforced by the perpendicular buttresses in facades. The number of inscribed prisms according varying inclination represent the versatility of the facade being capable of withstanding greater or lesser intensity of horizontal forces. A force of greater intensity will be faced by a prism with greater inclination but lower moment of inertia and vice versa. 
The angle with the horizontal and moment of inertia in $\mathrm{m} 4$ of each prism reflects this versatility, non-existent on facades of cathedrals "French type".

Figures 1 to 6. Ratio of surfaces by plant, parabolic arches and compressed prisms inscribed on the façades of the Cathedrals of Barcelona, Santa María del Mar, cathedrals of Tortosa and Manresa, Gates of Serrano and Bellver Castle. Sources: Images Selfelaboration.
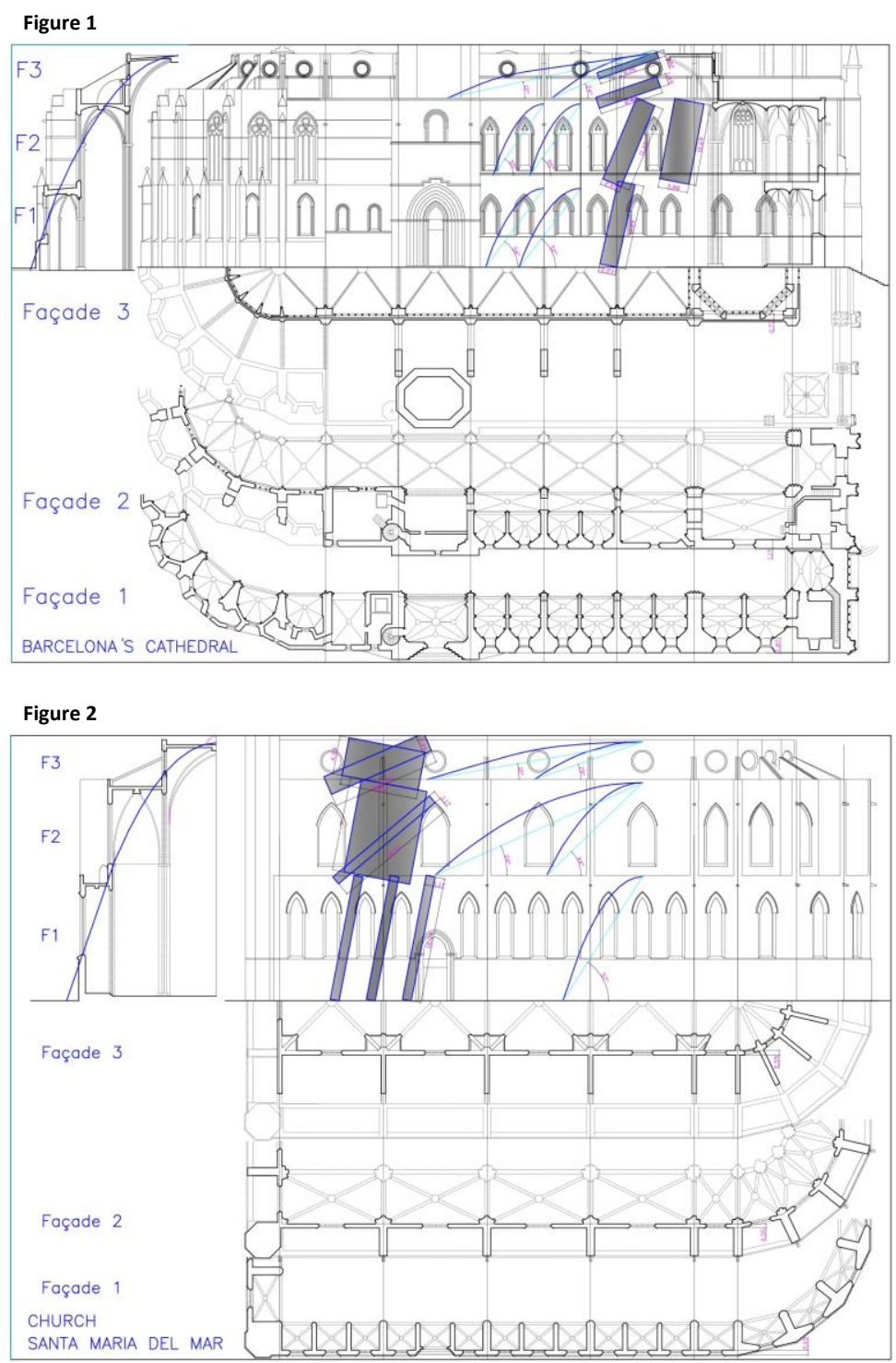

Figure 3

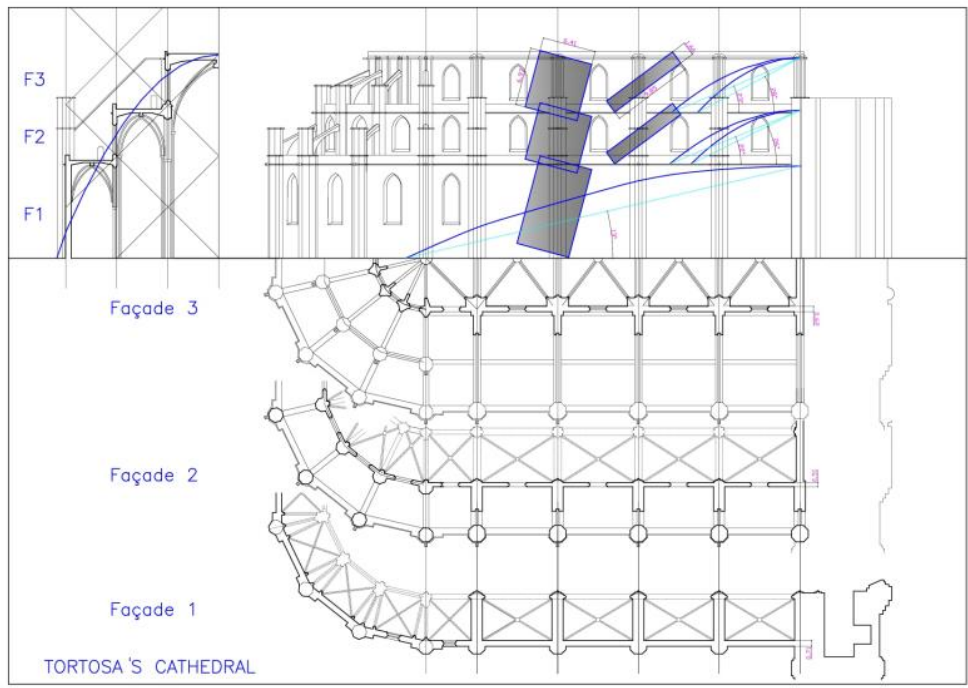


Figure 4

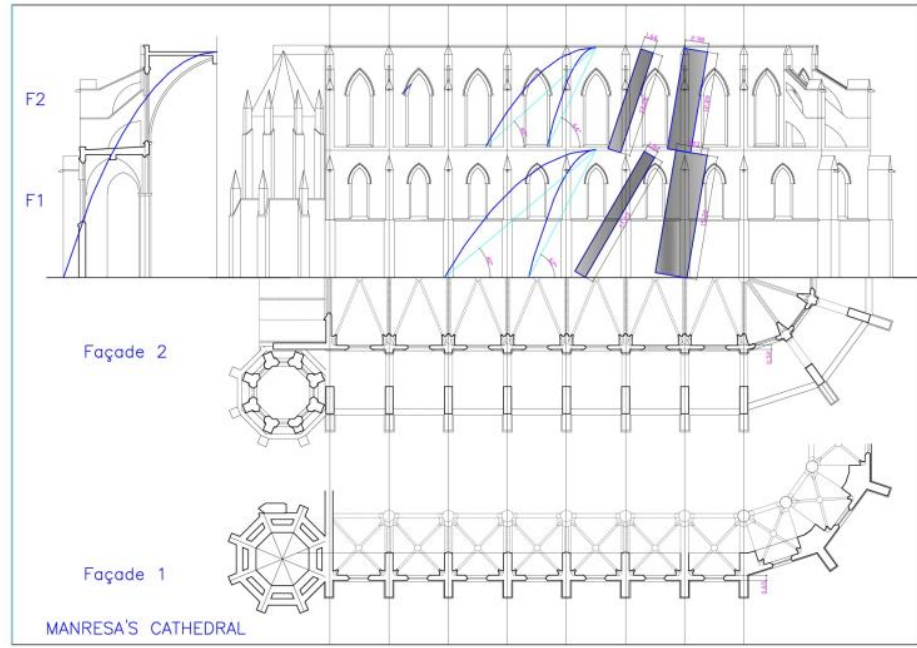

Figure 5

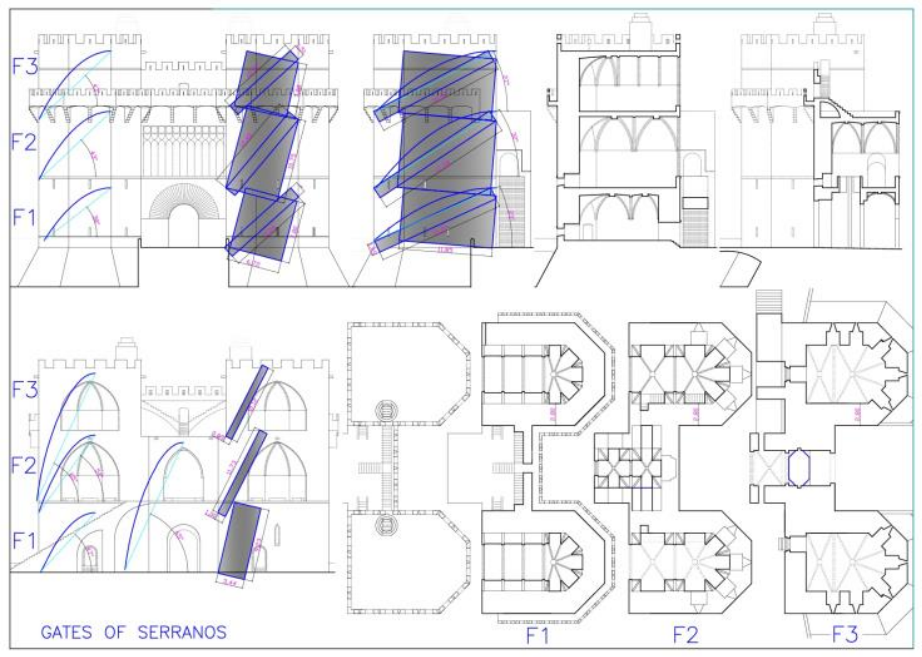

Figure 6

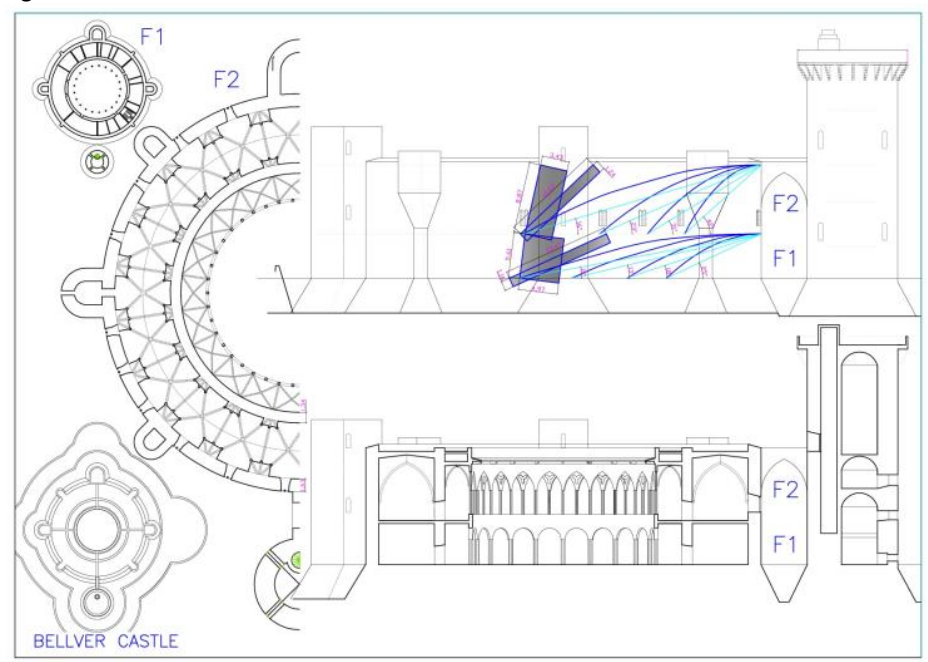


Table 1. Structure density. Relationship between area of facades and area of nave closed by them. Source: Self-elaboration.

\begin{tabular}{lccc}
\hline Façades & Santa María del Mar & Cathedral of Barcelona & Cathedral of Manresa \\
\hline 3rd façade & 0.15 & 0.20 & \\
2nd façade & 0.11 & 0.12 & 0.09 \\
1st façade & 0.12 & 0.15 & 0.11 \\
& Cathedral of Tortosa & Gates of Serranos & Bellver castle \\
\hline 3rd façade & 0.15 & 0.45 & \\
2nd façade & 0.09 & 0.41 & 0.23 \\
1st façade & 0.11 & 0.55 & 0.20 \\
\hline
\end{tabular}

Table 2. Ratio in Walls between vertical dimension window-flat roof/horizontal dimensions of walls between windows in Façades. Source: Self-elaboration.

\begin{tabular}{lccc}
\hline Façades & Santa María del Mar & Cathedral de Barcelona & Cathedral de Manresa \\
\hline $\begin{array}{l}\text { Vert. Lenght / } \\
\text { Horiz. lenght }\end{array}$ & 0.33 & 0.51 & 0.75 \\
$\begin{array}{l}\text { Vert. area/ } \\
\text { Horiz. area }\end{array}$ & 0.25 & 0.53 & 0.81 \\
& Cathedral de Tortosa & Gates of Serranos & Bellver castle \\
\hline $\begin{array}{l}\text { Vert. lenght/ } \\
\text { Horiz. lenght }\end{array}$ & 0.21 & 0.57 & 0.94 \\
$\begin{array}{l}\text { Vert. area/ } \\
\text { Horiz. area }\end{array}$ & 0.27 & 0.60 & 0.99 \\
\hline
\end{tabular}

The data of Cathedral of Barcelona and Santa María del Mar data obtained come from side façades. In Tortosa and Manresa come from the façade of the main nave.

Table 3. Angles to the horizontal between the base and vertex of the inscribed parabolic arches. Source: Self-elaboration.

\begin{tabular}{|c|c|c|c|c|c|c|}
\hline \multirow{2}{*}{$\begin{array}{l}\text { Façades } \\
\text { 3rd façade }\end{array}$} & \multicolumn{2}{|c|}{ Santa María del Mar } & \multicolumn{2}{|c|}{ Cathedral of Barcelona } & \multicolumn{2}{|c|}{ Cathedral of Manresa } \\
\hline & 10 은 & 190 & $13 ㅇ$ & 250 & & \\
\hline 2nd façade & 240 & 44 & 41 음 & $53 ㅇ$ & 42 & 640 \\
\hline \multirow[t]{2}{*}{ 1st façade } & \multicolumn{2}{|c|}{510} & 51 & 549 & 40 & $62^{\circ}$ \\
\hline & \multicolumn{2}{|c|}{ Cathedral of Tortosa } & \multicolumn{2}{|c|}{ Gates of Serranos } & \multicolumn{2}{|c|}{ Bellver castle } \\
\hline 3rd façade & $22 \circ$ & 310 & 270 & $22 \circ$ & \multicolumn{2}{|c|}{$31 ㅇ$} \\
\hline 2nd façade & 220 & 310 & $32 \circ$ & 22 & 31 은 & 320 \\
\hline 1st façade & \multicolumn{2}{|c|}{13 은 } & $23 ㅇ$ & $38^{\circ}$ & $13 ㅇ$ & 230 \\
\hline
\end{tabular}


Table 4. Horizontal angles and inertia moments of the inscribed inclined prisms.

\begin{tabular}{|c|c|c|c|c|c|c|}
\hline Façades & \multicolumn{2}{|c|}{ Cathedral of Tortosa } & \multicolumn{2}{|c|}{ Gates of Serranos } & \multicolumn{2}{|c|}{ Bellver of castle } \\
\hline 3rd façade & 3700.23 & 75013.50 & 2800.79 & $85 \div 384.34$ & & \\
\hline 2nd façade & 3700.20 & 75011.35 & 33ㅇ 0.79 & $85 \div 384.34$ & 43ㅇ 0.27 & 7705.46 \\
\hline 1st façade & \multicolumn{2}{|c|}{$75 ⒖ 50$} & 250 0.79 & 850385.32 & 2400.23 & $83 \circ 16.67$ \\
\hline Façades & \multicolumn{2}{|c|}{ Santa María del Mar } & \multicolumn{2}{|c|}{ Cathedral of Barcelona } & \multicolumn{2}{|c|}{ Cathedral of Manresa } \\
\hline 3rd façade & 2400.76 & 79050.50 & $19 \div 0.02$ & 1900.08 & & \\
\hline 2nd façade & 4000.08 & 79032.53 & 6701.09 & 7903.62 & $72 \div 0.20$ & $40 \div 0.08$ \\
\hline 1st façade & \multicolumn{2}{|c|}{7900.09} & 7801.50 & & $60 \div 0.19$ & $80 \div 3.62$ \\
\hline
\end{tabular}

Results

\section{Façade structure density}

The facades of the Cathedral of Barcelona have the highest density of structure on the ground floor with $15 \%$, which descends on second façade. This valor increases significantly in third facade at the level of the main nave up to $20 \%$. The massifs buttresses influence in values obtained in this façade which is subdivided in two sections with open clerestory opened to the interior and lighting circular windows.

Santa María del Mar has similar values in the 1st and 2nd facades, greatly increasing in the 3rd where more significant horizontal forces resist. The facades of the Manresa Cathedral have declining values as the height increases.

In Tortosa the façade structure density is comparatively similar to the other samples, estimated at $10 \%$ which increases to $14 \%$ for its 3 rd façade, as in Santa María del Mar.

Torres de Serranos with a ratio of $54 \%$ in first facade, $40 \%$ on second façade and increases to $44 \%$ in third facade. Bellver Castle reaches an area of ground floor of $20 \%$ and $22 \%$ on the first floor, where are added 4 perimeter towers on the walls of the terraces.

All the samples have big density on ground floor, decreases in intermediate floor and increase in the floors located at higher elevations. These values match very properly with the analysis carried out so far.

\section{Ratio dimensions vertical / horizontal between gaps}

Comparing existing dimensions in vertical and horizontal between windows, the Cathedral of Tortosa has the most effective design against earthquake, with a ratio of $1 / 5$. The façade of Santa María del Mar reachs a ratio of $1 / 3$. If we relate the resistant areas of wall between the windows, Santa Maria has the most effective façades with a ratio of 1/4.

The façade of the Cathedral of Barcelona have similar values for lengths and areas being the most effective with a ratio of $1 / 2$. The facades that reflect worse values with a ratio of $3 / 4$ are in the Manresa Cathedral.

The Gates of Serranos offers a ratio of $1 / 2$ in the façade that overlooks the city. Bellver Castle, with a minimum proportion of hollow on the walls, has a really high value close to 1 . Loses sense, because the defensive function of the building and the large thickness of its facades, carry out this analysis. Their façades have not a minor resistance than the rest, on the other hand, their facades are able to contain the resistant buttresses that face internal and diagonal efforts, as in the Gates of Serranos.

\section{Inscription of parabolic arches}

Santa María del Mar has the best configuration in its 3rd façade at the height of the main nave, where resist the biggest horizontal strength. The cathedrals of Barcelona and Tortosa have a 3rd façade that register many parabolic 
arches lines. The Cathedral of Barcelona has a 3rd facade more complex to accommodate a triforium in height, subdividing into two this facade. The highest zone houses the oculus.

Gate of Serranos, with three stories and not inclined parabolic arches, completes this classification, because the cathedral of Manresa and Bellver have only two levels, by lacking this facade.

Santa Maria del Mar and Tortosa in churches have better configuration in the 2nd façade, being exceeded clearly by Bellver Castle that registers greater variety of parabolic arches. The worst configuration is located in the Cathedral of Barcelona, due to the large number and height of its Windows. In this case is collected inside the buttresses inserted in the façades that occupies the 1st and 2 nd façades.

Tortosa outperforms the other sample in its first facade of chapels completely blind, followed by the facades of the Manresa Cathedral, and finally Barcelona and Santa María del Mar. The first facade of Bellver Castle houses a better value than Gates of Serranos.

\section{Inscription of compressed prisms: angle with the horizontal and moments of inertia}

Santa María de Mar is the most stable of all the churches in his 3rd facade where the main nave. We can register resistant prisms with high moments of inertia and even overcomes the cathedral of Tortosa. The Cathedral of Barcelona has the higher number of horizontal prisms but in very few resistance.

Santa Maria del Mar and Tortosa have a 2 nd facade with a very similar resistance, surpassing the others. Their registered prisms can be more horizontal, not as the Cathedral of Barcelona. The Manresa Cathedral outperforms the rest at the level of chapels. In fortifications, the facades of the gates of Serranos overcome in stability even the churches and the Bellver Castle by having more horizontal prisms and higher inertia moment. It is important to be considered there are not gaps except the loopholes on the main level.

The range of registered prisms and parabolic arcs shows the versatility of design in Mediterranean Gothic Façades, able of withstanding the higher intensity of horizontal forces. The façades of Santa María del Mar have the higher values, accompanied by façades of Cathedral of Tortosa, completed later and more slowly in time. Gates of Serranos exceed even the hermetic façades of Bellver, despite having three storeys and a much more vertical proportion.

The medieval Masters of the Mediterranean Gothic applied his best intuition to solve the seemingly insoluble problem of to build cathedrals or Gothic fortifications in seismic zones. If these "recipes" were not reflected in medieval books as the Villard de Honnecourt (2015) drawings, the same churches as Santa María del Mar, Barcelona, Tortosa Cathedral or the gates of Serranos demonstrate how their facades are capable of withstanding considerable forces at its highest levels. They were designed with a knowledge and expertise far superior to the usual ones, without the need of previous models constituting building types that faced and rationally solved the problem posed by the presence of the earthquake.

Santa María del Mar, the Cathedral of Barcelona, the Cathedral of Tortosa and the gates of Serranos are built to zero metres above sea level opposed to churches and fortifications built to highest levels like Bellver Castle or far from the sea as the Manresa Cathedral. This factor adds uncertainty to the presence of the earthquake that made to maximize stability in their facades (Meli \& Sánchez, 2007). Criteria and experiences on structural rehabilitation of stone masonry buildings in Mexico City (Meli \& Sánchez, 2007).

All this analysis is basic to undertake new restorations of our facades, privileging criteria such as the sustainability of interventions in time, postulated in the Krakow Charter, following structural and design criteria that will be respected at the same time guaranteeing the authenticity of the monument (Ossio \& Prado, 2008. "Evolución de los criterios de intervención utilizados en los Monumentos Nacionales de Santiago de Chile". Revista de la Construcción № 7. Pontificia Universidad Católica de Chile). 
Cassinello, M.J. (2005). Influence of the historical earthquakes in the construction of the Spanish Gothic cathedrals. Annali di Architettura: rivista del Centro Internazionale di Studi di Architettura Andrea Palladio, 17, 9-20.

Meli, R. (1975). Comportamiento sísmico de muros de mampostería. UNAM, Instituto de Ingeniería, Series del Instituto de Ingeniería 352 , México.

Meli, R. \& Sánchez, R. (1997). Considerations on the seismic safety of historical monuments. 11th World Conference on Earthquake Engineering. Paper No. 2087, Elsevier Science Ltd.

Meli,R. \& Sánchez, R. (2007) . Criteria and experiences on structural rehabilitation of stone masonry buildings in Mexico City. International Journal of Architectural Heritage, 1 (1).

Meli, R. (1998) Ingeniería estructural de los edificios históricos. Fundación ICA, México D F.

Ossio, F. \& Prado, F. (2008). Evolución de los criterios de intervención utilizados en los Monumentos Nacionales de Santiago de Chile. Revista de la Construcción, 7.

Villard de Honnecourt. (2015). "Carnet" 33 folios of annotated drawings include Laon, Reims, and Chartres Cathedrals. BNF Gallica. http://gallica.bnf.fr/ark:/12148/btv1b10509412z 